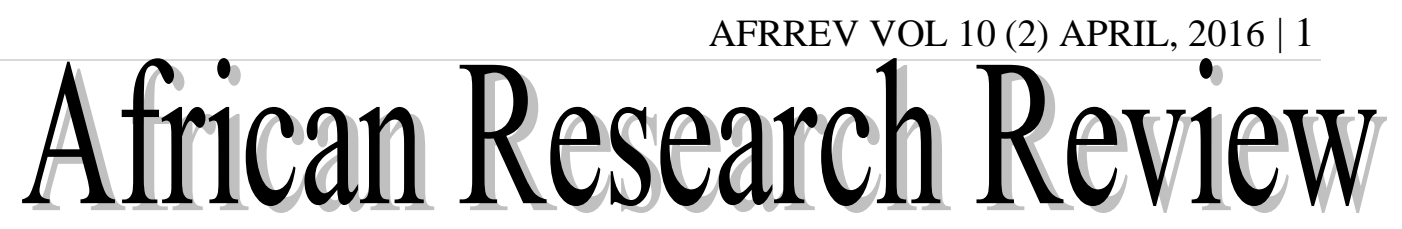

An International Multi-disciplinary Journal, Ethiopia

Vol. 10(2), Serial No.41, April, 2016: 1-15

ISSN 1994-9057 (Print) ISSN 2070-0083 (Online)

Doi: http://dx.doi.org/10.4314/afrrev.v10i2.1

\title{
Leadership Style and Employee Behaviour: A Reciprocal Relationship
}

\author{
Domfeh, Kwame Ameyaw \\ Department of Public Administration \\ University of Ghana Business School \\ University of Ghana \\ P. O. Box 25, Legon, Accra \\ E-mail: kadomfeh@ug.edu.gh; Kwadomfeh@yahoo.com
}

\section{Obuobisa-Darko, Theresa}

Department of Public Administration

University of Ghana Business School

University of Ghana

P. O. Box 25, Legon, Accra

E-mail: tobuobisa@yahoo.co.uk

$\&$

\section{Asare, Lawrence Offei \\ Department of Public Administration \\ University of Ghana Business School \\ University of Ghana \\ P. O. Box 25, Legon, Accra \\ E-mail: Law_asare@yahoo.com}


AFRREV VOL 10 (2) APRIL, 2016 | 2

\begin{abstract}
An effective leader is one who has a purpose and is able to influence his followers to enable them achieve that goal successfully. This paper adopted the literature review research method to look at the cause and effect relationship between the leader and followers. Information was collected from multiple databases as well as textbooks. Areas considered included the definition of leadership and the cause and effect relationship between leaders and followers, by identifying the influence leaders have on employee behaviour, specifically performance and voluntary turnover. It was identified that Leadership, explained as a systematic process where individual(s) influence(s) others towards the achievement of desired goals in interpersonal relationship, has influence on employees, specifically their performance and voluntary turnover. For further studies, it is suggested that data is gathered and analysed to confirm or refute the finding of this relationship between leaders and their followers in both private and public sector organisations.
\end{abstract}

Keywords: Leadership, Leadership styles, Employee performance, Turnover intention

\title{
Introduction
}

A leader is an individual who selects, equips, trains and influences one or more follower(s) who have diverse gifts, abilities, skills and focuses on the organisation's mission and objectives causing the follower(s) to willingly and enthusiastically expend spiritual, emotional and physical energy in a concerted coordinated effort to achieve the organisational mission and objectives (Winston and Patterson, 2006). The term "leadership" is so nebulous that no one has ever been able to measure it and yet everyone has tried to define it (Brookes, 2014). It is one of the concepts fraught with definitional confusion. However, what is certain about it is, it deals with people in relationship (Fairholm and Fairholm, 2009) and is a process not a person (Van Wart, 2013).

Leadership has been explained as a reciprocal relationship between those who choose to lead and those who decide to follow and it is not something you do to people but something you do with people (Binfor et al, 2013). Again, according to Wang et al, (2005) there is a reciprocal process in the exchange relationship between leader and follower where each party brings to the relationship different kinds of reasons for exchange. This depicts the point that there is a relationship between the leader and followers and both should work together. The existence of a reciprocal relationship will affect employees and this paper aims at clarifying this effect on employee performance and voluntary turnover.

\section{Methodology}

Copyright $\odot$ IAARR 2007-2016: www.afrrevjo.net

Indexed African Journals Online: www.ajol.info 
AFRREV VOL 10 (2) APRIL, 2016 |3

The study adopted the literature review research method which is described as a relevant research approach aimed at summarising the current extant body of literature related to a phenomenon (Chermack and Passmore, 2005). The study used multiple databases and the key words were keyed into the various databases to search for relevant information.

Both empirical and conceptual papers were considered. It should be noted that in most cases articles considered were from peer reviewed journals that were published in English language. The paper entails information on varied definitions of leadership, leadership and employee performance, leadership and employee turnover and last being conclusion and recommendation for further studies.

\section{The Concept of Leadership}

Organisations need strong leadership for optimal effectiveness (Robbins and Judge, 2009) since leadership is an antecedent to employee behaviour. Hussein and da Costa (2008), citing Bennis and Nanus (2003), indicated that regardless of the type of organisation (government agencies, institutions or small enterprises), the central and most effective factor required to enhance the use of human resources is leadership. All groups and teams need leadership (Jones et al, 2000) which according to Howell and Costley (2006) is a fascinating social phenomenon that occurs in all groups of people regardless of geography, culture, or nationality.

Even though there is no consensus on the definition of leadership, it is viewed generally as a reciprocal process in which both leader and follower exist in a dyadic mutual relationship (Livi et al, 2008; Phillips \& Gully, 2012; Binfor et al, 2013). Robbins and Judge (2009) defined leadership as the ability to influence a group toward the achievement of a vision or set goals. The source of this influence, according to them, may be formal, based on the possession of managerial rank in the organisation or informal. It is in a similar vein that Howell and Costley (2006) defined leadership as a process used by an individual to influence members within a group toward the achievement of its goals and group members view the influence as legitimate.

Similarly, Cole (2002) described leadership as a dynamic process that works in a group whereby one individual over a particular period of time, and in a particular organisational context, influences that other group members to commit themselves freely to the achievements of group tasks or goals. Majority of definitions available on leadership reflect the assumption that it involves a process where there is intentional influence by one person over other people to guide, structure and facilitate activities and relationships in a group or organisation (Yukl, 2006). Leadership can thus be explained as a systematic process where individual(s) influence(s) others towards the achievement of desired goals and this happens in all interpersonal relationship. The 
AFRREV VOL 10 (2) APRIL, 2016 | 4

foregoing indicate that leadership is about influence on people and there its cause and effect relationship established.

\section{Leadership Theories}

Several leadership theories exist that explain the reciprocal relationship between the leader and followers. These theories according to Gibson et al, (2009) can be looked at based on leadership trait, behaviour and situational factors, while McShane and Glinow (2007) indicated the leadership theories can be organised into five main perspectives - Competency (Trait) perspective, Behavioural perspective, Contingency perspective, Transformational perspective and Implicit leadership perspective. A review of leadership literature reveals evolving series of 'schools of thought' from 'Great Man' and 'Traits' theories to 'Behavioural' theories to 'Transformational' leadership. These schools of thought have been summarised by Bolden et al, (2003) as contained in Appendix 1

\section{Leadership Styles}

Several styles of leadership like Charismatic leaders, Authentic Leaders, Transformational leaders and Transactional leaders among others exist in literature. However, Popli and Rizvi (2015) believe that effective leaders know how to switch between these styles and are able to choose appropriate style to maximize influence. Irrespective of these different types of styles that exist Srithongrung (2011) opine that the contemporary leadership literature divides leadership styles into two main types: Transformational and transactional which Robbins and Judge (2009) have indicated are the best leaders. Some researchers have thus suggested that for effective leadership there should have a balance between transformational and transactional leadership (Chandan \& Devi, 2014).

\section{Leadership Styles and Employee Behaviour}

This section presents information on the effect leadership styles and employee behaviour, specifically employee performance and voluntary turnover. Leadership is a major factor which contributes immensely to the general wellbeing of organisations and nations (Odumeru \& Ifeanyi, 2013). Effective leadership behaviour according to Buelens et al, (2006) is based on both the willingness of the manager to help subordinates and the need of subordinate for help.

Successful leaders have one thing in common; that is, they influence those around them in order to reap maximum benefit its most vital and expensive resourceits people. For instance, leadership enhances employee desires to remain in the organisation (Ali, 2009; Ng'ethe et al, 2012; Al-Sharifi and Rajiani, 2013), influence their performance (Judge et al, 2004; Walumbwa et al, 2011; Obiwuru et al, 2011), 
AFRREV VOL 10 (2) APRIL, 2016 | 5

level of commitment (Dhammika et al, 2013), satisfaction (Voon et al, 2011), engagement (Nohria et al, 2008) and stimulate their utmost efforts to accomplish the organisation's goals.

\section{Leadership and Employee Performance}

Leadership has a positive influence towards employee performance (Shahab and Nisa, 2014) and therefore play important roles to ensure the increase of organisation and individual performance (Gul et al, 2012). Performance, explained as the accomplishment, execution, carrying out, working out of anything ordered or undertaken (Armstrong, 2010), is greatly influenced by leadership style (Walumbwa et al. 2011).

In order to stimulate and influence subordinates' extra-role behaviours, public managers may consider acting as role models for their subordinates by demonstrating extraordinary technical ability, being persistent in coping with difficult tasks, and by acknowledging the employees' value and input (Srithongrung, 2011). As a result of this, employees will be motivated to put in more effort to improve their performance.

Other researchers have also confirmed the effect of leadership on performance. For instance, Phillips and Gully (2012) suggested that at its best, leadership inspires and motivates employees to work hard towards organisational objectives and help the organisation succeed. Armstrong further indicated that high performance comes about as a result of appropriate behaviour, especially discretionary behaviour and the effective use of required knowledge, skills and competencies which is influenced among other things the by leadership style. Thus, employees choose to perform the tasks as a result of their identification with the leader.

Studies on leadership have identified positive relationship between leadership style, particularly transformational leaders and performance at various levels (Dvir et al, 2002; Howell et al, 2005). For instance, there empirical evidence that leadership behaviour positively influences organisational performance (Howell et al, 2005; Dvir et al, 2002; Shafie et al, 2013). At the employee level too research confirms the effect leadership has on individual performance (Shafie et al, 2013; Obicci, 2015; VigodaGadot, 2006).

This confirms a study by Paracha et al, (2012) who after a survey to determine whether leadership style (transformational and transactional) has an impact or able to influence employee performance found that there is a significant positive association between the styles leaders adopt and employee performance and therefore important that organisations carefully analyse the kind of style they adopt if they want to increase employee performance. This may be because transformational leaders help individuals 
AFRREV VOL 10 (2) APRIL, 2016 | 6

transcend their self-interest for the sake of the larger vision of the organisation (Vera and Crossan 2004), thus will put in their best for it to be achieved. If leaders therefore exert the individualised consideration behaviour (Transformational leaders) like recreation activities after work, team building tours, it will boost the understanding between the leaders and subordinates which will result in improved employee job performance (Ha and Nguyen, 2014).

Nemanich and Keller (2007) after conducting a field study concluded that transformational leadership behaviour had a positive relationship with acquisition acceptance and supervisor-rated performance. This may be because one of the characteristics of a transformational leader -intellectual stimulation- makes them appeal to followers' sense of logic and analysis by challenging them to think creatively and find solutions to difficult problems (Hartog et al, 1997; Mullins, 1999; Robbins and Judge, 2009; Antonakis et al, 2003). Thus, when employees have this strong emotional ties to their managers, feel that their opinions count, and believe their managers have an interest in their development (i.e. emotional engagement), they are more likely to positively respond to their managers and produce favourable outcomes that help the managers to be effective (Luthans and Peterson, 2002).

Again, a study by Piccolo and Colquitt (2006) using 283 respondents, found that transformational leaders' behaviour had a significant direct effect on task performance of employees. This may be because transformational leaders through intellectual stimulation are able to encourage their subordinates to reframe problems, take risks and approach old situations in new ways (Vera and Crossman, 2014). which may enable them outperform their competitors.

The foregoing indicates that there is a relationship between leadership style and employee performance and therefore with the adoption of appropriate leadership styles, leaders will be able to influence employees to perform to the best of their ability

\section{Leadership and Employee Turnover}

Employee turnover, a process through which employees leave the organisation, according to Tse and Lam (2008) has been a central research topic for nearly 90 years and has been identified that it can result in severe negative consequences for organisation (Abbasi \& Holman, 2000). It is a key issue concerning organisations, regardless of the location, size, nature of business or business strategy because it is costly (Long et al, 2012).

The role of leaders in employee retention is critical since their leadership style play key role in determining whether the employee will leave or stay ( $\mathrm{Ng}^{\prime}$ ethe et al, 2012). Retention can be classified and categorised into voluntary or involuntary, as 
AFRREV VOL 10 (2) APRIL, 2016 |7

well as functional or dysfunctional each having varying degrees of impact on the organisation (Wells and Peachey, 2011; Watrous et al, 2006).

Managers are striving hard to overcome this challenge by using different strategies because it has been identified that there is a direct negative relationship between transformational and transactional leadership behaviour on one hand and voluntary organisational turnover intention (Wells and Peachey, 2011).

The relationship between leadership and turnover intention has been explored by a number of researchers (Gul et al, 2012; Hamstra et al, 2011; Al-Sharifi, and Rajiani, 2013) confirming the cause and effect relationship between leadership style and turnover intention. Results of these studies generally show that leadership is a factor in mitigating turnover intention even though results from a study carried out by Sellgren et al, (2007) on the relationship between leadership behaviour of nursing managers and staff turnover revealed that there is no significant relationship between leadership behaviour and staff turnover.

Contrary to the findings of Sellgren et al, (2007), several researchers found that leadership has an effect on performance. A study carried out by Essien et al, (2013) to determine the relationship between managerial style and staff turnover in Nigerian banks revealed that there exists a positive relationship between managerial style and turnover. They therefore recommended that to have a satisfactory and productive workforce, it is prudent that organisations design and fashion out effective managerial style that will enhance employee performance and retain them.

Again, in a study by Ng'ethe et al, (2012) in public universities in Kenya using 547 academic staff members, it was established that leadership style inversely and significantly influences intentions of staff to leave the organisation and therefore the need to adopt leadership style that encourages the retention of staff to help it thrive. This finding supports the outcome of an earlier study by Dimaculangan and Aguiling (2012) whose study focused on the direct and indirect effects of transformational and transactional leadership on salespersons turnover intention and found that transformational leadership directly decrease turnover intention and indirectly reduce turnover intention through perceived ethical climate. This may be because transformational leaders recognise individual uniqueness (Individualised consideration), link their needs to the organisation's needs and provide mentoring and growth opportunities (Robyn and Du Preez, 2013). when this happens employee feel worthy and therefore not likely to quit.

One other study conducted by Liu et al (2013) exploring an approach on how culturally-specific human resource management (HRM) should moderate the relationship between leadership style and employee turnover revealed that leadership 
AFRREV VOL 10 (2) APRIL, 2016 8

style i.e. leader-member exchange can have a significant effect on employee turnover. The effective management of the human resource of an organisation involves the provision of the needed resources and when leaders do this will reduce turnover. This assertion is based on the fact that employees who perceive they have the physical, emotional, and psychological resources necessary for the completion of work are less likely to have an intention to turnover (Shuck et al, 2011). Thus, to be effective, leaders should provide all resources needed to ensure that employees continue to be with the organisation.

It can thus be concluded that there is a relationship between leadership style and employee turnover intention and thus leaders in organisations should ensure the appropriate style is adopted to help retain employees in organisation.

\section{Conclusion}

Positive relationship between leaders and followers is important in every organisation because, according to Carstens and Barnes (2006) the quality of the relationships has influence on issues like teamwork, group accountability, performance standards, subordinate growth or role interchangeability which, in turn, influence individual and business performance. The discussion has confirmed that leadership is a reciprocal relationship that exists between the leader and the follower.

With leadership potentially playing such a vital role towards the performance and voluntary turnover of employees, it is useful to consider the different types of leadership and their potential impact on employees to ensure leaders in organisations adopt the appropriate style to ensure success of the organisation. For further research, it is suggested that empirical data is gathered on specific leadership styles like authentic leadership and charismatic leadership to identify the extent to which it impacts on employee performance and voluntary turnover intention. 
AFRREV VOL 10 (2) APRIL, 2016 |9

\section{Appendix 1}

\section{Summary of Leadership Theories}

\begin{tabular}{|c|c|}
\hline Great Man theories & $\begin{array}{l}\text { Based on the belief that leaders are exceptional } \\
\text { people, born with innate qualities, destined to lead. } \\
\text { The use of the term 'man' was intentional since } \\
\text { until the latter part of the twentieth century } \\
\text { leadership was thought of as a concept which is } \\
\text { primarily male, military and Western. This led to } \\
\text { the next school of Trait Theories }\end{array}$ \\
\hline Trait Theories & $\begin{array}{l}\text { The lists of traits or qualities associated with } \\
\text { leadership exist in abundance and continue to be } \\
\text { produced. They draw on virtually all the adjectives } \\
\text { in the dictionary which describe some positive or } \\
\text { virtuous human attribute, form ambition to zest for } \\
\text { life. }\end{array}$ \\
\hline Behaviourist Theories & $\begin{array}{l}\text { These concentrate on what leaders actually do } \\
\text { rather than on their qualities. Different patterns of } \\
\text { behaviours are observed and categorized as 'styles } \\
\text { of leadership'. This area has probably attracted } \\
\text { most attention from practicing manager, e.g. } \\
\text { McGregor's theory X and theory Y. }\end{array}$ \\
\hline Situational Leadership & $\begin{array}{l}\text { This approach sees leadership as specific to the } \\
\text { situation in which it is being exercised. For } \\
\text { example, whilst some situations may require an } \\
\text { autocratic style, others may need a more } \\
\text { participative approach. It also presupposes that } \\
\text { there may be differences in required leadership } \\
\text { styles at different levels in the same organization. }\end{array}$ \\
\hline Contingency Theory & $\begin{array}{l}\text { This is a refinement of the situational viewpoint } \\
\text { and focuses on identifying the situational variables } \\
\text { which best predict the most appropriate or } \\
\text { effective leadership styles to fit the particular } \\
\text { circumstances, e.g., Fiedler's contingency theory, } \\
\text { the path-goal theory, Leader-Member Exchange } \\
\text { theory. }\end{array}$ \\
\hline
\end{tabular}


AFRREV VOL 10 (2) APRIL, 2016 | 10

\begin{tabular}{|l|l|}
\hline \multirow{2}{*}{ Transactional Theory } & $\begin{array}{l}\text { This approach emphasizes the importance of the } \\
\text { relationship between leader and followers, } \\
\text { focusing on the mutual benefits derived from a } \\
\text { form of 'contract' through which the leader } \\
\text { delivers such things as rewards or recognition in } \\
\text { return for the commitment or loyalty of the } \\
\text { followers. }\end{array}$ \\
\hline Transformational Theory & $\begin{array}{l}\text { The central concept here is change and the role of } \\
\text { leadership in envisioning and implementing the } \\
\text { transformation of organizational performance. }\end{array}$ \\
\hline
\end{tabular}

Source: Bolden, Gosling, Marturano, and Dennison (2003)

\section{Reference}

Abbasi, S. M. \& Hollman, K.W. (2000). Turnover intention: The real bottom line. Public Personnel Management, 29(3), 333-342

Al-Sharifi, H. \& Rajiani, L. (2013). Leadership practices and talent turnover, study on Yemeni organisations. Business and Management Research, 2(3), 60-67

Ali, N. (2009). Factors affecting overall job satisfaction and turnover intention, Journal of Managerial Sciences, 2(2), 239-252

Antonakis, J., Avolio, B.J. \& Sivasubramaniam, N. (2003). Context and leadership: an examination of the nine-factor full range leadership theory using the multifactor leadership questionnaire. The Leadership Quarterly, 14, 261-295

Armstrong, M. (2010). Armstrong's essential human resource management practices: A guide to people management. London: Kogan Page.

Binfor, F. Boateng, S.K., Osei, S.A. Swanzy, F.K.M, \& Gyebi-Garbrah, T.F. (2013). The effect of leadership styles and motivation on employee performance in public institutions: Evidence from Ghana. International Journal of Current Research, 5(9), 2667-2670

Bolden, R., Gosling, J. Marturano, A. \& Dennison, P. (2003). A review of leadership theory and Competency frameworks, Centre for leadership studies, University of Exeter, United Kingdom, Retrieved on February 20, 2015 from http//: centers.exeter.ac.uk/cls/documents/mgmt.sandardspdf 
AFRREV VOL 10 (2) APRIL, 2016 | 11

Brookes, S. (2014). Is selfless leadership an impossible ideal for public leaders? The International Journal of Leadership in Public Services, 10(4), 200 - 216

Buelens, M., Broeck, H.V., Vanderheyden, K., Kreitner, R. \& Kinicki, A. (2006). Organizational behavior, (3rd ed.). Berkshire: McGraw-Hill education.

Carstens, F.J. \& Barnes, N. (2006). The quality of leader/employee relationship in business performance. SA Journal of Human Resource Management, 4(2), 1019.

Chandan, C. L. \& Devi, R. (2014). A Literature Review On Leadership Styles.Research Journal's Journal of Management, 2(2), 1-10

Chermack T. J. \& Passmore, D. L. (2005). Using journals and databases in research. In R.A. Swanson \& E. F. Holton III (Eds.) Research in organisations: Foundations and methods of inquiry (pp 401-418), San Francisco, CA: BerrettKoehler

Cole, G. A. (2002). Personnel and human resource management, (5th ed.). London: Thomson South Western.

Dhammika, K.A.S., Ahmad, F. B. \& Sam, T.L. (2013). Transactional, transformational, union and organisational commitment: An examination of the effect flaws. International Journal of Business and Social Sciences, 4(6), 103-111

Dimaculangan, E. D. \& Aguiling, H. (2012). The effects of transformational leadership on salesperson's turnover intentions. International Journal of Business and Social Science, 3(19), 197-210

Dvir, T.M., Eden, D., Avolio, B. J. \& Shamir, B. (2002). Impact of transformational leadership on follower development and performance: a field experiment. Academy of Management Journal, 45(5), 735-744

Essien, E. A., Adekunle, O.A. \& Oke-Bello, A.M. (2013). Managerial style and staff turnover in Nigerian banks: A comparative analysis. American International Journal of Social Sciences, 2(6), 79-93

Fairholm, M. R. \& Fairholm, G. W. (2009). Understanding leadership perspectives, theoretical and practical applications. New York: Springer.

Gibson, J. L., Ivancevich, J. M., Donnely, J. H. \& Konopaske, R. (2009). Organizations Behaviour, Structure, Process, (13th ed.). Boston: McGraw-Hill Irwin.

Gul, S., Ahmad, B., Rehman, S.U., Shabir, N. \& Razzaq, N. (2012). Leadership styles, turnover intentions and the mediating role of organisational commitment. Information and Knowledge Management, 2(7), 44-51. 
AFRREV VOL 10 (2) APRIL, 2016 | 12

Ha, N. M. \& Nguyen, T. V. H. (2014). The influence of leadership behaviour on employee performance in the context of software companies in Vietnam, Advances in Management and Applied Economics, 4(3), 157-171.

Hamstra, M. R. W., Yperen, N. W. V., Wisse, B. \& Sassenberg, K. (2011). Transformational-Transactional leadership styles and followers' regulatory focus, fit reduces followers' turnover intensions, Journal of personnel psychology, 10(4), 182-186.

Hartog, D. N. D., Van Muijen, J.J. \& Koopman, P. L. (1997). Transactional versus transformational leadership: an analysis of the MLQ. Journal of Occupational and Organisational Psychology, 70, 19-34.

Howell, J. P. \& Costley, D. L. (2006). Understanding behaviours for effective leadership (2nd ed.). New Jersey, Pearson, Prentice Hall.

Howell, J. M., Neufeld, D.J. \& Avolio, B.J. (2005). Examining the relationship of leadership and physical distance with business unit performance. The Leadership Quarterly, 16, 273-285

Hussein, M. F. \& da Costa, J. L. (2008). Organisational commitment and its relationship to perceived leadership style in an Islamic school in a large urban centre in Canada: Teachers perspective. Journal of Contemporary Issues in Education, 3(1), 17-38

Jones, G. R., George, J. M. \& Hill, C. W. L. (2000). Contemporary management, (2nd ed.). Boston: McGraw Hill.

Judge, T. A., Piccolo, R. F. \& Ilies, R. (2004). The forgotten ones? The validity of consideration and initiating structure in leadership research. Journal of Applied Psychology, 89(1), 36-51

Liu, Z., Cai, Z., Li, J., Shi, S. \& Fang, Y. (2013). Leadership style and employee turnover intentions: a social identity perspective. Career Development International, 18(3), 305-324

Livi, S., Kenny, D. A., Albright, L. \& Pierro, A. (2008). A social relations analysis of leadership. The Leadership Quarterly, 19, 235- 248.

Long, C. S., Thean, L.Y., Ismail, W.K.W. \& Jusah, A (2012). Leadership styles and employees' turnover intentions: Exploratory study of Academic staff in a Malaysian college. World Applied Sciences Journal, 19(4), 574-581

Luthans, F. \& Peterson, S. J. (2002). Employee engagement and manager self-efficacy. Journal of Management Development, 21(5), 376-387 
AFRREV VOL 10 (2) APRIL, 2016 | 13

McShane, S. L. \& Glinow, M. A. V. (2007). Organizational behaviour (essentials), Boston, McGraw-Hill Irwin

Mullins, L.J. (1999). Management and organisational behaviour, (5th ed.). New York, Prentice Hall

Nemanich, L.A. \& Keller, R.T. (2007). Transformational leadership in an acquisition: a field study of employees, The Leadership Quarterly, 18, 49-68.

Ng'ethe, J. M., Namusonge, G. S. \& Iravo, M. A. (2012). Influence of leadership style on academic staff retention in public universities in Kenya, International Journal of Business Social Sciences, 3(21), 297-302.

Nohria, N., Groysberg, B. \& Lee, L-E (2008). Employee motivation, a powerful model, Harvard business review, July-August.

Obicci, P.A. (2015). Effects of ethical leadership on employee performance in Uganda. Net Journal of Business Management, 3(1), 1-12

Obiwuru, T. C., Okwu, A.T. Akpa, V. O. \& Nwankwere, I. A. (2011). Effects of leadership style on organizational performance: A survey of selected small scale enterprises in Ikosi- Ketu Council development area of Lagos state, Nigeria, Australian Journal of Business and Management Research 1(7). $100-111$

Odumeru, J., A. \& Ifeanyi, G. O. (2013). Transformational vs. transactional leadership theories: Evidence in literature. International Review of Management and Business Research, 2(2), 355-361

Popli, S. \& Rizvi, I. A. (2015). Exploring the relationship between service orientation, employee engagement and perceived leadership style: a study of managers in the private service sector organizations in India. Journal of Services Marketing, 29(1), 59 - 70,

Paracha, M. U. Qamar, A., Mirza, A., Hassan-I-U, \& Waqus, H. (2012). Impact of leadership style (transformational and transactional leadership) on employee performance and mediating role of job satisfaction, study of private school (Educator) in Pakistan. Global Journal of Management and Business Research, 12(4), 55-64.

Phillips, J. M. \& Gully, S. M. (2012). Organisational behaviour tools for success. Mason, South-Western Cengage learning. 
AFRREV VOL 10 (2) APRIL, 2016 | 14

Piccolo, R. F. \& Colquitt, J. A. (2006). Transformational leadership and job behaviours: The mediating role of core characteristics, Academy of Management Journal, 49(2), 327-340.

Robbins, S. P. \& Judge, T.A. (2009). Organisational behaviour, (13th ed.). New Jersey Pearson, Prentice Hall.

Robyn, A. \& DuPreez, R. (2013). Intention to quit amongst generation Y academics in higher education. SA Journal of Industrial Psychology, 39(1), 1-14

Sellgren, S., Ekval, G. \& Tomson, G. (2007). Nursing staff turnover: Does leadership matter? Leadership in Health Services, 20(3), 169-183

Shahab, M. A. \& Nisa, I. (2014). The influence of leadership and work attitudes towards job satisfaction and performance of employees. International Journal of Managerial Studies and research, 2(5), 69-77

Shafie, B., Baghersalimi, S. \& Barghi, V. (2013). The relationship between leadership style and employee performance, case study of real estate registration organisation of Tehran province, Singaporean Journal of Business Economics and Management Studies, 2(5), 21-29.

Shuck, B., Reio, T.G.Jr. \& Rocco, T.S. (2011). Employee engagement: an examination of antecedents and outcome variables. Human Resource Development International, 14(4), 427-445

Srithongrung, A. (2011). The causal relationship among transformational leadership, organisational commitment and employee effectiveness. International Journal of Public Administration, 34, 374-388.

Tse, H. H. M. \& Lam, W. (2008). Transformational leadership and turnover: The roles of LMX and organisational commitment. Academy of management proceedings Anaheim, CA, 8-13, August pp 1-6.

Van Wart, M. (2013). Administrative leadership theory: A reassessment after 10 years. Public Administration, 91(3), 521-543.

Vera, D. \& Crossan, M. (2014). Strategic leadership and organisational learning, The Academy of Management Review, 29(2), 222-240.

Vigoda-Godot, E. (2006). Leadership style, organisational politics and employees' performance: an empirical examination of two competing models. Personnel Review, 36(5), 661-683.

Voon, M. L., Lo, M. C., Ngui, K. S. \& Ayob, N. B. (2011). The influence of leadership styles on employee job satisfaction in public sector organization Malaysia. 
AFRREV VOL 10 (2) APRIL, 2016 | 15

International Journal of Business, Management and Social Sciences, 2(1), 2432 ,

Walumbwa, F. O., Mayer, D. M., Wang, P., Wang, H., Workman, K. \& Christensen, A. L. (2011). Linking ethical leadership to employee performance: The roles of leader-member exchange, self-efficacy and organisational identification. Organisational Behaviour and Human Decision Processes, 115, 204-213

Wang, H., Law, K. S, Hackett, R. D., Wang, D. \& Chen, Z. (2005). Leader-member exchange as a mediator of the relationship between transformational leadership and followers' performance and organisational citizenship behaviour. Academy of Management Journal, 48(3), 420-432.

Watrous, K.M., Huffman, A.N. \& Pritchard, R.D. (2006). When co-workers and managers quit: The effects of turnover and shared values of performance, Journal of Business and Psychology, 21(1), 103-126

Winston, B. E. \& Patterson, K. (2006). An integrative definition of leadership, International Journal of Leadership Studies, 1(2), 6-66

Wells, J.E. \& Peachey, J.W. (2010). Turnover intentions, do leadership behaviour and satisfaction with the leader matter? Team Performance Management, 17(1/2), 23-40

Yukl G. (2006). Leadership in organisations, $\left(6^{\text {th }}\right.$ ed.). New Jersey: Pearson Prentice Hall. 